\title{
ANALISIS HUBUNGAN JARAK DAN KEDALAMAN DENGAN STRUKTUR KOMUNITAS LAMUN DI PANTAI PANCURAN, KEPULAUAN KARIMUNJAWA
}

\author{
The Relationship Analysis of Distance and Depth on The Structure of Seagrass Community \\ in Pancuran Beach, Karimunjawa Island \\ Muhammad Gaffar Ridho, Supriharyono*), Arif Rahman \\ Program Studi Manajemen Sumberdaya Perairan, Departemen Sumberdaya Akuatik \\ Fakultas Perikanan dan Ilmu Kelautan, Universitas Diponegoro \\ Jl. Prof. Soedarto, SH. Tembalang, Semarang, Jawa Tengah - 50275, Telp/Fax +6224 7474698 \\ Email : gaffarmuhammad@gmail.com
}

\begin{abstract}
ABSTRAK
Pantai Pancuran adalah salah satu lokasi konservasi padang lamun di Taman Nasional Karimunjawa dengan vegetasi padang lamun. Penelitian ini dilaksanakan pada bulan April 2018 dengan tujuan untuk mengetahui hubungan jarak dan kedalaman dengan struktur komunitas lamun yang meliputi kerapatan dan indeks keanekaragamannya. Materi yang digunakan adalah lamun, dengan menggunakan metode deskripsi eksploratif yang bersifat observasi dengan objek yang diteliti di lapangan. Teknik pengambilan sampel menggunakan kuadran transek ukuran 1x1 meter yang tersebar di 3 stasiun berdasarkan jarak dan kedalaman serta terdapat 6 plot pada setiap stasiunnya. Parameter lingkungan yang diamati meliputi jarak dan kedalaman, nitrat dan fosfat sedimen, salinitas, suhu, derajat keasaman $(\mathrm{pH})$, kecerahan, kecepatan arus, pasang surut, dan karakteristik sedimen. Hubungan jarak dan kedalaman dengan struktur komunitas lamun diproses menggunakan analisis regresi dan korelasi. Hasil penelitian ini didapatkan 6 jenis lamun yaitu Thalassia hemprichii, Cymodocea rotundata, Halophila ovalis, Syringodium isoetifolium, Enhalus acoroides, dan Halodule pinifolia. Karakteristik sedimen didominasi oleh pasir halus sebanyak 34,960\%. Korelasi jarak dan kedalaman dengan struktur komunitas lamun diperoleh nilai $\quad(r=-0,717)$ pada kerapatan dan $(r=0,894)$ pada indeks keanekaragaman.
\end{abstract}

Kata Kunci : Struktur Komunitas Lamun; Jarak; Kedalaman; Pantai Pancuran

\section{ABSTRACT}

Pancuran Beach is one of the seagrass conservation areas in Karimunjawa National Park. This study was conducted in April 2018, in order to investigate the relation of distance and depth on the structure of seagrass community which included the density and index of diversity. The method used in this study is seagrass, using explorative description method that is observation to the object study in the field. The sampling technique uses a 1xI meter transect quadrant spread over 3 stations based on distance and depth with includes 6 plots at each station. Environmental parameters observed include distance and depth, sediment of nitrate and phosphate, salinity, temperature, acidity (pH), brightness, current velocity, tides, and sediment characteristics. The relationship between distance and depth on the structure of seagrass community processed by regression and correlation analysis. The results of the study found 6 types of seagrass, there were Thalassia hemprichii, Cymodocea rotundata, Halophila ovalis, Syringodium isoetifolium, Enhalus acoroides, and Halodule pinifolia. Sediment characteristics were dominated is fine sand of 34.960\%. The correlation of distance and depth on the structure of seagrass community resulted a value $(r=-0,717)$ for density and $(r=0,894)$ for index of diversity.

Keywords : Structure Of Seagrass Community; Distance; Depth; Pancuran Beach

*) Penulis Penanggungjawab

\section{PENDAHULUAN}

Taman Nasional Karimunjawa adalah salah satu kawasan pelestarian alam di Kabupaten Jepara, Propinsi Jawa Tengah yang memiliki ekosistem asli. Taman Nasional ini dikelola dengan sistem zonasi yang dapat dimanfaatkan untuk tujuan penelitian, ilmu pengetahuan, pendidikan, menunjang budidaya, pariwisata dan rekreasi. Ekosistem Karimunjawa terbagi atas lima tipe ekosistem yaitu hutan hujan tropis dataran rendah, hutan pantai, hutan mangrove, ekosistem lamun dan ekosistem terumbu karang. Dengan segala potensi yang ada di dalamnya, wilayah tersebut telah dijadikan penyangga 
kehidupan bagi 8.842 penduduk yang selama ini berinteraksi dengan ekosistem di sekelilingnya. (BTNKJ, 2004). Pulau Karimunjawa merupakan salah satu pulau utama dari bagian Taman Nasional Karimunjawa selain Pulau Kemujan dan Pulau Parang. Pulau Karimunjawa merupakan pulau terbesar dibandingkan dengan pulau lainya yang berada di kepulauan Karimunjawa dengan luas 4.302,50 Ha (BTNKJ, 2008).

Lamun (Seagrass) merupakan tumbuhan berbunga (angiospermae) yang seluruh siklus hidupnya berada di perairan laut.Dalam susunan ekosistem perairan, persebaran lamun berada diantara terumbu karang menuju arah laut dan mangrove menuju ke tepian pantai. Posisi ini menjadikan lamun memiliki fungsi strategis di ekologi perairan sebagai penahan arus bawah laut dan perangkap sedimen untuk memperkecil potensi adanya abrasi. Menurut Dobo (2009), lamun memegang peranan penting di kawasan pesisir karena merupakan penyangga dari ekosistem mangrove dan terumbu karang. Lamun merupakan produsen primer dengan produktivitas dan bahan organik yang tinggi. Lamun tumbuh di zona intertidal bawah dan subtidal atas hingga mencapai kedalaman $30 \mathrm{~m}$ (Hutomo, 1997). Persebaran lamun diperairan memiliki hubungan yang kuat dengan jarak dan kedalaman, semakin dalam suatu perairan maka intensitas cahaya matahari untuk menembus dasar perairan menjadi terbatas dan kondisi ini akan menghambat laju fotosintesis lamun di dalam air. Secara umum, jarak mempengaruhi lamun secara horizontal dan berkaitan dengan kedalaman serta pasang surut sebagai faktor yang mempengaruhi kerapatan dan pertumbuhan lamun (Sambara, 2014).

Tujuan penelitian ini adalah untuk mengetahui informasi terbaru mengenai kondisi lamun dan faktor-faktor yang mempengaruhinya khususnya hubungan dengan jarak dan kedalaman terhadap struktur komunitas lamun.

\section{MATERI DAN METODE PENELITIAN}

\section{a. Alat dan Bahan}

Alat yang digunakan dalam penelitian Struktur Komunitas Lamun di Pantai Pancuran Kepulauan Karimunjawa meliputi kuadran transek, papan data, secchi disk, roll meter, hand counter, ceklis lamun, refraktometer, $\mathrm{pH}$ papper, plastik zipper, thermometer, global positioning system (GPS), current meter, pipa paralon dan kamera. Bahan yang digunakan dalam penelitian ini yaitu lamun dan sedimen yang terdapat di wilayah penelitian.

\section{b. $\quad$ Metode Penelitian}

Metode yang digunakan dalam penelitian ini yaitu metode deskripsi eksloratif. Metode deskripsi eksploratif merupakan penelitian yang bersifat observasi terhadap suatu objek di lingkungan alaminya, tanpa ada perlakuan terhadap objek yang diteliti. Menurut Arikunto (2002) bahwa metode deskriptif eksploratif merupakan penelitian dengan menyajikan data secara sistematik berdasarkan fakta yang ada di lapangan. Metode ini bertujuan untuk melihat keadaan suatu fenomena dan menggambarkanya dengan tidak menguji hipotesa.

\section{c. Penentuan Lokasi Penelitian}

Penentuan lokasi penelitian menggunakan metode Purposive Sampling. Metode Purposive Sampling dipilih oleh pengamat dengan menyesuaikan dengan konten yang akan menjadi bahan penelitian sesuai dengan tujuan pengamatan. Terdapat 3 stasiun yang akan menjadi lokasi penelitian, setiap stasiun memiliki 6 titik kuadran (plot). Penentuan stasiun didasarkan pada jarak dan kedalaman, hal ini dilakukan untuk mengetahui adanya hubungan antara struktur komunitas lamun dengan jarak dan kedalaman yang berbeda. Jarak disesuaikan antara bibir pantai dengan peletakan kuadran perstasiunnya. Stasiun satu memiliki jarak 11 meter, stasiun dua berjarak 45 meter, dan stasiun tiga berjarak 85 meter. Penentuan jarak ini juga didasarkan terhadap adanya kisaran kedalaman. Kedalaman dalam penelitian ini dijadikan patokan dalam penentuan stasiun yang akan digunakan sebagai area penelitian. Stasiun 1 memiliki kedalaman 0,5 meter, stasiun 2 memiliki kedalaman 1 meter, dan stasiun 3 memiliki kedalaman 1,5 meter. Penelitian ini dilakukan selama 3 hari pada jam 08.00-10.00 pada setiap stasiun, hal ini dilakukan untuk meminimalisir adanya perbedaan kedalaman yang diakibatkan oleh pasang surut.

\section{d. Pengolahan Data}

Pengolahan data meliputi perhitungan terhadap struktur komunitas lamun yang terdiri kerapatan, penutupan, frekuensi, indeks nilai penting, indeks keanekaragaman, indeks keseragaman dan indeks dominansi. Data yang sudah didapatkan kemudian dihitung dengan rumus :

\section{Kerapatan Jenis (Ki) dan Kerapatan Relatif (KRi)}

Keterangan :

$$
K i=\frac{N i}{A}
$$

$\mathrm{Ki}=$ Kerapatan jenis ke-i

$\mathrm{Ni}=$ Jumlah total individu dari jenis ke-i

\footnotetext{
${ }^{\circledR}$ Copyright by Management of Aquatic Resources (MAQUARES)
} 
$\mathrm{A}=$ Luas area total pengambilan sampel $\left(\mathrm{m}^{2}\right)$

Sumber : Fachrul (2007)

Keterangan :

$$
K R i=\frac{N i}{\sum N i}
$$

$\mathrm{KRi}=$ Kerapatan relatif ke-i

$\mathrm{Ni}=$ Jumlah individu spesies ke-i

$\sum N i=$ Jumlah individu seluruh spesies

Sumber : Fachrul (2007)

\section{Frekuensi Jenis (Fi) dan Frekuensi Relatif (FR)}

Keterangan :

$$
F i=\frac{P i}{\sum P i}
$$

$\mathrm{Ki}=$ Kerapatan jenis ke-i

$\mathrm{Ni}=$ Jumlah total individu dari jenis ke-i

$\mathrm{A}=$ Luas area total pengambilan sampel $\left(\mathrm{m}^{2}\right)$

Sumber : Fachrul (2007)

Keterangan :

$$
F R=\frac{F i}{\sum F i}
$$

$\mathrm{FR}=$ Frekuensi relative

$\mathrm{Fi}=$ Frekuensi jenis ke-i

$\sum F i=$ Jumlah frekuensi untuk seluruh jenis

Sumber : Fachrul (2007)

Penutupan Jenis (Ci) dan Penutupan Relatif (RCi)

$$
\mathrm{PJ}=\frac{\mathrm{ai}}{\mathrm{A}}
$$

Keterangan :

PJ = Penutupan lamun jenis ke-I $\left(\% / \mathrm{m}^{2}\right)$

ai $=$ Luas total penutupan jenis ke-I (\%)

A = Jumlah total area yang ditutupi lamun $\left(\mathrm{m}^{2}\right)$

Sumber : Tuwo (2011)

$$
R C i=\frac{\text { Penutupan jenis ke }-\mathrm{i}}{\text { Penutupan seluruh jenis }}
$$

\section{Indeks Nilai Penting (INP)}

Keterangan :

INP = Indeks nilai penting

$\mathrm{FR}=$ Frekuensi relatif

Sumber : Brower et al (1990)

Indeks Keanekaragaman (H')

$$
\begin{aligned}
& \mathrm{INP}=\mathrm{FR}+\mathrm{KR}+\mathrm{PR} \\
& \mathrm{PR}=\text { Penutupan relatif } \\
& \mathrm{KR}=\text { Kerapatan relati }
\end{aligned}
$$

\footnotetext{
${ }^{\circledR}$ Copyright by Management of Aquatic Resources (MAQUARES)
} 
Keterangan :

$\mathrm{H}^{\prime}$ = Indeks keanekaragaman

$\mathrm{Pi}=$ Proporsi jumlah individu jenis ke-I dari jumlah total individu $(\mathrm{Ni} / \mathrm{N})$

$\mathrm{S}=$ Jumlah jenis

Sumber : Krebs (1989)

Klasifikasi indeks keanekaragaman Shannon-Wienner adalah sebagai berikut:

$\mathrm{H}^{\prime}<1=$ Indeks keanekaragaman rendah

$1 \leq \mathrm{H}^{\prime} \leq 3$ = Indeks keanekaragaman sedang

$\mathrm{H}^{\prime}>3$ = Indeks keanekaragaman tinggi

\section{Indeks Keseragaman (E)}

$$
E=\frac{H^{\prime}}{\mathrm{H}^{\prime} \max }=E=\frac{H^{\prime}}{\mathrm{LnS}}
$$

Keterangan:

$\mathrm{H}^{\prime}=$ Indeks keanekaragaman Shannon-Wiener

H'max $=$ LnS (Indeks keanekaragaman maksimum)

$\mathrm{S}=$ Jumlah jenis

Sumber : Krebs (1989)

Menurut Krebs (1989), indeks keseragaman berkisar antara 0-1, dimana:

$0,6-1=$ Keseragaman spesies tinggi

$0,4<\mathrm{e}<0,6 \quad=$ Keseragaman spesies sedang

$0-0,4 \quad=$ Keseragaman spesies rendah

\section{Indeks Dominansi $(\mathbf{C})$}

$$
C=-\sum_{n=1}^{s}(\mathrm{n} / N i)^{2}=\sum_{n=1}^{s} P i^{2}
$$

Keterangan:

$\mathrm{ni}=$ Jumlah individu jenis ke-i

$\mathrm{N}=$ Total nilai kepentingan

Sumber : Krebs (1989)

Nilai indeks dominansi Simpson berkisar antara 0 - 1, dengan kriteria sebagai berikut:

$\mathrm{C}=0$, berarti didalam komunitas tidak ada jenis yang dominan atau komunitas berada dalam keadaan stabil.

$\mathrm{C}=1$, berarti didalam komunitas ada dominasi dari jenis tertentu atau komunitas berada dalam keadaan tidak stabil.

\section{e. Analisis Regresi dan Korelasi}

Pendugaan hubungan antara jarak dan kedalaman dengan struktur komunitas lamun menggunakan regresi dan korelasi linier sederhana dengan menggunakan program Microsoft excel, variabel tetapnya (x) adalah jarak dan kedalaman dan variabel (y) adalah struktur komunitas lamun yang terdiri dari nilai kerapatan dan indeks keanekaragaman lamun. Tabel 1. Interpretasi koefisien korelasi

\begin{tabular}{lll}
\hline No & Nilai & Keterangan \\
\hline 1. & $0,00-0,199$ & Sangat rendah \\
$\mathbf{2 .}$ & $0,20-0,399$ & Rendah \\
3. & $0,40-0,599$ & Sedang \\
$\mathbf{4 .}$ & $0,60-0,799$ & Kuat \\
$\mathbf{5 .}$ & $0,80-1,000$ & Sangat kuat \\
\hline
\end{tabular}

Sumber : Sugiyono (2007)

\section{HASIL DAN PEMBAHASAN}

a. Hasil

Berdasarkan hasil penelitian, parameter lingkungan dapat dilihat pada Tabel 2.

${ }^{\circ}$ Copyright by Management of Aquatic Resources (MAQUARES) 
Tabel 2. Parameter Lingkungan

\begin{tabular}{cccc}
\hline $\begin{array}{c}\text { Parameter } \\
\text { Jarak/Kedalaman }\end{array}$ & $\begin{array}{c}\text { Stasiun I } \\
(\mathbf{1 1 / 0 . 5} \text { Meter })\end{array}$ & $\begin{array}{c}\text { Stasiun II } \\
\mathbf{( 4 5 / 1} \text { Meter })\end{array}$ & $\begin{array}{c}\text { Stasiun III } \\
(\mathbf{8 0 / 1 . 5} \text { Meter })\end{array}$ \\
\hline Nitrat Sedimen (mg/l) & 17,452 & 11,452 & 12,245 \\
Fosfat Sedimen (mg/l) & 2,454 & 2,505 & 2,819 \\
Kecerahan & $100 \%$ & $100 \%$ & $100 \%$ \\
Suhu $\left({ }^{\circ} \mathrm{C}\right)$ & 31 & 30 & 29,5 \\
Salinitas (\%o) & 35 & 34 & 34 \\
pH & 8 & 7 & 7 \\
Kec. Arus (m/s) & 0,166 & 0,125 & 0,076 \\
Pasang Surut & $-5,567$ & $-6,086$ & $-7,413$ \\
\hline
\end{tabular}

Hasil parameter lingkungan pada ekosistem lamun di Pantai Pancuran, Karimunjawa secara umum masuk kedalam kategori optimum yang mendukung pertumbuhan dan perkembangan lamun. Perubahan nilai pada setiap stasiun tidak ada yang signifikan. Nilai nitrat tertinggi berada pada stasiun 1, nilai fosfat tertinggi pada stasiun 3, kecerahan merata pada setiap stasiun. Nilai suhu, $\mathrm{pH}$, kecepatan arus dan salinitas tertinggi berada pada stasiun 1, dan pasang surut terendah berada pada stasiun 3 dengan nilai $-7,413$.

Berdasarkan hasil penelitian, karakteristik sedimen dapat dilihat pada Tabel 3.

Tabel 3. Karakteristik Sedimen

\begin{tabular}{cccc}
\hline Fraksi Sedimen & Partikel & Ukuran Butir $(\mathbf{m m})$ & Persentase (\%) \\
\hline Batu & Kerikil & 4,76 & 12,02 \\
& Butiran & 3,36 & 5,49 \\
Pasir & Pasir sangat kasar & 2 & 6,03 \\
& Pasir kasar & 0,841 & 12,83 \\
& Pasir sedang & 0,25 & 17,80 \\
& Pasir halus & 0,149 & 34,96 \\
& Pasir sangat halus & 0,074 & 10,87 \\
\hline
\end{tabular}

Analisis komponen sedimen yang telah dilakukan, diperoleh persentase sedimen di Pantai Pancuran, Kepulauan Karimunjawa yang terdiri dari dua fraksi sedimen yaitu batu dan pasir. Sedimen di Pantai Pancuran didominasi oleh partikel pasir halus dengan persentase $34,96 \%$ dan persentase terendah yaitu partikel butiran dengan nilai 5,49\%.

Berdasarkan hasil penelitian, kerapatan jenis lamun dapat dilihat pada Tabel 4.

Tabel 4. Kerapatan Jenis Lamun

\begin{tabular}{llccc}
\hline No & Nama Spesies & $\begin{array}{l}\text { Stasiun I } \\
\left(\mathrm{ind} / \mathrm{m}^{2}\right)\end{array}$ & $\begin{array}{l}\text { Stasiun II } \\
\left(\mathrm{ind} / \mathrm{m}^{2}\right)\end{array}$ & $\begin{array}{l}\text { Stasiun III } \\
\left(\mathrm{ind} / \mathrm{m}^{2}\right)\end{array}$ \\
\hline 1. & Thalassia hemprichii & 77 & 0 & 13 \\
2. & Cymodocea rotundata & 156 & 25 & 42 \\
3. & Halophila ovalis & 10 & 0 & 0 \\
4. & Syringodium isoetifolium & 25 & 0 & 3 \\
5. & Enhalus acoroides & 0 & 46 & 55 \\
6. & Halodule pinifolia & 0 & 21 & 23 \\
\hline
\end{tabular}

Kerapatan lamun pada stasiun 1 menunjukan nilai tertinggi pada jenis Cymodocea rotundata dengan nilai 156 individu/ $\mathrm{m}^{2}$. Pada stasiun 2 dan 3 jenis Enhalus acoroides memiliki nilai kerapatan tertinggi dengan nilai masingmasingnya 46 individu $/ \mathrm{m}^{2}$ dan 55 individu $/ \mathrm{m}^{2}$.

Berdasarkan hasil penelitian, penutupan lamun dapat dilihat pada Tabel 5.

Tabel 5. Penutupan Lamun

\begin{tabular}{lllll}
\hline \multirow{2}{*}{ No } & \multirow{2}{*}{ Nama Spesies } & $\begin{array}{l}\text { Stasiun I } \\
\text { RCi }(\%)\end{array}$ & $\begin{array}{l}\text { Stasiun II } \\
\text { RCi }(\%)\end{array}$ & $\begin{array}{l}\text { Stasiun III } \\
\text { RCi }(\%)\end{array}$ \\
\hline 1. & Thalassia hemprichii & 33,884 & 0 & 7,799 \\
2. & Cymodocea rotundata & 50,964 & 20,977 & 26,741 \\
3. & Halophila ovalis & 8,540 & 0 & 0 \\
4. & Syringodium isoetifolium & 6,612 & 0 & 2,786 \\
5. & Enhalus acoroides & 0 & 54,885 & 41,226 \\
6. & Halodule pinifolia & 0 & 24,138 & 21,448 \\
& Jumlah & $\mathbf{1 0 0}$ & $\mathbf{1 0 0}$ & $\mathbf{1 0 0}$ \\
\hline
\end{tabular}

${ }^{\circledR}$ Copyright by Management of Aquatic Resources (MAQUARES) 
Penutupan lamun pada stasiun 1 menunjukan nilai tertinggi pada jenis Cymodocea rotundata dengan nilai penutupan 50,964\%. Sementara itu, pada stasiun 2 dan 3 jenis Enhalus acoroides memiliki penutupan tertinggi dengan nilai masing-masingnya $54,885 \%$ dan $41,226 \%$.

Berdasarkan hasil penelitian, frekuensi lamun dapat dilihat pada Tabel 6.

Tabel 6. Frekuensi Lamun

\begin{tabular}{lllll}
\hline \multirow{2}{*}{ No } & \multirow{2}{*}{ Nama Spesies } & $\begin{array}{l}\text { Stasiun I } \\
\text { FR }(\%)\end{array}$ & $\begin{array}{l}\text { Stasiun II } \\
\text { FR }(\%)\end{array}$ & $\begin{array}{l}\text { Stasiun III } \\
\text { FR }(\%)\end{array}$ \\
\hline 1. & Thalassia hemprichii & 37,500 & 0 & 10,526 \\
2. & Cymodocea rotundata & 37,500 & 21,429 & 26,316 \\
3. & Halophila ovalis & 18,750 & 0 & 0 \\
4. & Syringodium isoetifolium & 6,250 & 0 & 5,263 \\
5. & Enhalus acoroides & 0 & 42,857 & 31,579 \\
6. & Halodule pinifolia & 0 & 35,714 & 26,316 \\
& Jumlah & $\mathbf{1 0 0}$ & $\mathbf{1 0 0}$ & $\mathbf{1 0 0}$ \\
\hline
\end{tabular}

Frekuensi lamun pada stasiun 1 menunjukan nilai tertinggi pada jenis Cymodocea rotundata dan Thalassia hemprichii dengan nilai yang sama yaitu 37,500\%. Sementara itu, pada stasiun 2 dan 3 jenis Enhalus acoroides memiliki frekuensi tertinggi dengan nilai masing-masingnya $42,857 \%$ dan $31,579 \%$.

Berdasarkan hasil penelitian, indeks nilai penting lamun dapat dilihat pada Tabel 7.

Tabel 7. Indeks Nilai Penting (INP)

\begin{tabular}{|c|c|c|c|c|}
\hline No & Nama Spesies & $\begin{array}{c}\text { Stasiun I } \\
(\%)\end{array}$ & $\begin{array}{c}\text { Stasiun II } \\
(\%)\end{array}$ & $\begin{array}{c}\text { Stasiun III } \\
(\%)\end{array}$ \\
\hline 1. & Thalassia hemprichii & 100,169 & 0 & 27,832 \\
\hline 2. & Cymodocea rotundata & 146,782 & 69,195 & 84,168 \\
\hline 3. & Halophila ovalis & 30,841 & 0 & 0 \\
\hline 4. & Syringodium isoetifolium & 22,207 & 0 & 10,271 \\
\hline 5. & Enhalus acoroides & 0 & 148,384 & 113,422 \\
\hline No & Nama Spesies & $\begin{array}{c}\text { Stasiun I } \\
(\%)\end{array}$ & $\begin{array}{c}\text { Stasiun II } \\
(\%)\end{array}$ & $\begin{array}{c}\text { Stasiun III } \\
(\%)\end{array}$ \\
\hline 6. & $\begin{array}{l}\text { Halodule pinifolia } \\
\text { Jumlah }\end{array}$ & $\begin{array}{l}0 \\
300\end{array}$ & 82,421 & $\begin{array}{l}64,307 \\
300\end{array}$ \\
\hline
\end{tabular}

Indeks Nilai Penting (INP) menunjukan bahwa Cymodocea rotundata ditemukan pada setiap stasiun dengan nilai yang berkisar antara 69,195-146,782. Hal ini menunjukan bahwa Cymodocea rotundata mempunyai pengaruh yang besar, mendominasi dan luas pesebarannya daripada jenis lainnya.

Berdasarkan hasil penelitian, indeks ekologi komunitas lamun dapat dilihat pada Tabel 8. Tabel 8. Indeks Ekologi Komunitas

\begin{tabular}{lllll}
\hline No. & Stasiun & H' & E & C \\
\hline 1. & Stasiun 1 & 1,013 & 0,730 & 1 \\
2. & Stasiun 2 & 1,033 & 0,940 & 1 \\
3. & Stasiun 3 & 1,335 & 0,829 & 1 \\
\hline
\end{tabular}

Indeks ekologi komunitas dari stasiun 1 sampai stasiun 3 menunjukan nilai indeks keanekaragaman yang terus meningkat dan masuk dalam kategori keanekaragaman sedang. Nilai keseragaman meningkat pada setiap stasiun dan masuk kedalam kategori keseragaman tinggi, hal ini berbanding lurus dengan nilai indeks dominansi yang tinggi yang menunjukan adanya spesies yang mendominasi pada setiap stasiunnya.

\footnotetext{
${ }^{\circ}$ Copyright by Management of Aquatic Resources (MAQUARES)
} 
Hubungan antara jarak dan kedalaman dengan struktur komunitas lamun yang meliputi kerapatan dan indeks keanekaragaman dapat dilihat pada Gambar berikut ini :

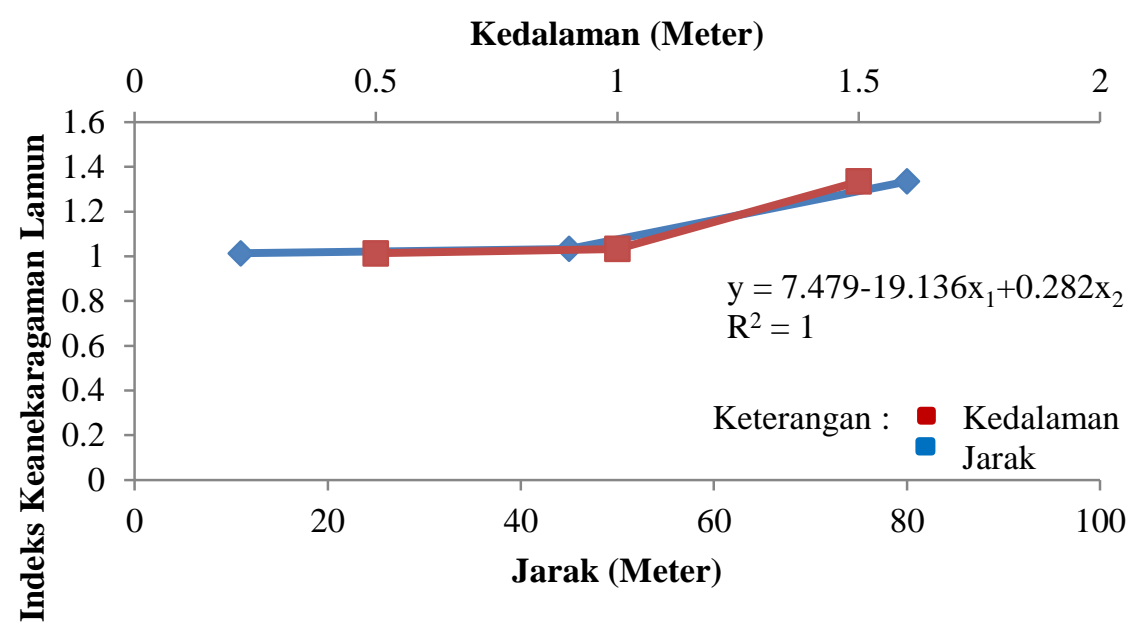

Gambar 1. Hubungan Jarak dan Kedalaman dengan Indeks Keanekaragaman

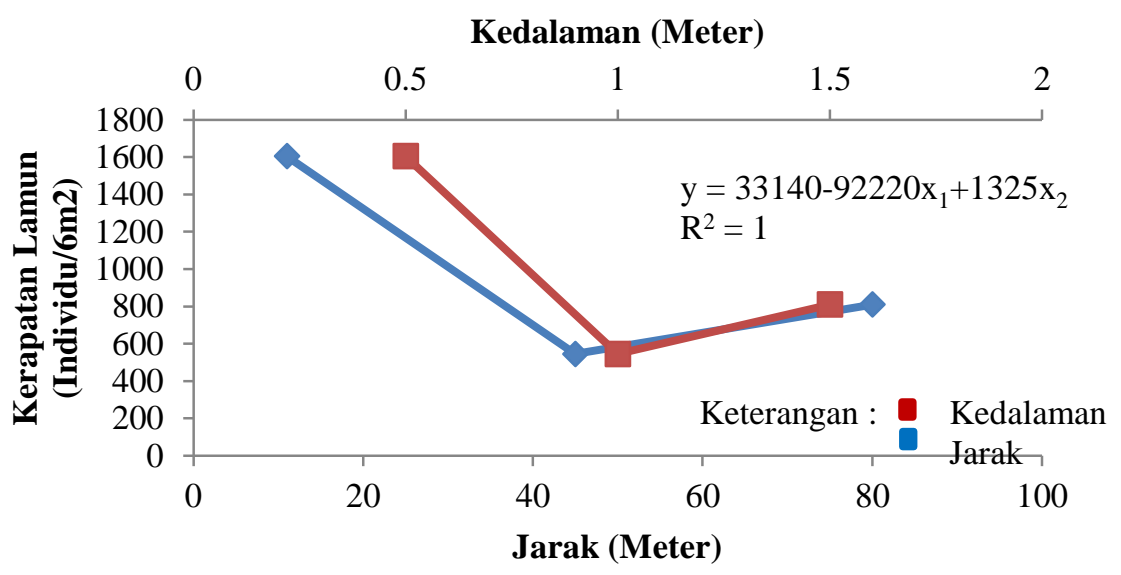

\section{b.
Kualitas Perairan \\ Kualitas Perairan}

Gambar 2. Hubungan Jarak dan Kedalaman dengan Kerapatan Lamun

Berdasarkan hasil penelitian terhadap parameter kualitas perairan di Pantai Pancuran, Kepulauan Karimunjawa yang didasarkan dari adanya perbedaan jarak dan kedalaman pada setiap stasiunnya maka diperoleh konsentrasi nitrat sedimen pada stasiun 1 dengan jarak 11 meter dan kedalaman 0,5 meter sebesar 17,452 mg/l, stasiun 2 dengan jarak 45 meter dan kedalaman 1 meter memiliki nilai 11,452 mg/l, dan stasiun 3 dengan jarak 80 meter dan kedalaman 1,5 meter memiliki nilai 12,245 mg/l. Menurut Risamasu dan Prayitno (2011), kandungan konsentrasi nitrat yang terlalu tinggi juga bisa menjadi ancaman, salah satunya yaitu perkembangan alga dan fitoplankton yang berbahaya yang dikenal dengan istilah Harmful Algae Blooms (HABs) yang menyebabkan terbatasnya kandungan oksigen terlarut di perairan.

Konsentrasi fosfat pada sedimen di Pantai Pancuran berkisar antara 2,454 mg/l sampai dengan 2, $819 \mathrm{mg} / \mathrm{l}$. Konsentrasi ini menunjukan bahwa kandungan fosfat sedimen di Pantai Pancuran semakin meningkat berdasarkan adanya perbedaan jarak dan kedalaman. Menurut Zhang et al., (2014) menjelaskan bahwa sedimen merupakan tempat penyimpanan dan pelepas material nutrient ke kolom air di perairan muara dan pantai.

Nilai salinitas di Pantai Pancuran pada stasiun 1 sampai stasiun 3 secara berurutan yaitu 35\%, 34\%, dan 34\%o. Nilai salinitas ini menunjukan perubahan nilai yang tidak signifikan. Nilai salinitas di stasiun 2 dan 3 nilainya lebih kecil karena adanya percampuran dengan air tawar yang berasal dari pancuran yang terdapat di dekat stasiun 2 dan 3 . Hal ini diperkuat oleh Millerro dan Sohn (1992), bahwa salinitas di permukaan sangat khas dan bervariasi. Nilai-nilai salinitas pada permukaan dipengaruhi oleh proses fisik yang terjadi di perairan. Salinitas akan meningat karena penguapan dan pembekuan. Salinitas akan menurun akibat intensitas hujan, aliran sungai, dan mencairnya es. Perbedaan antara penguapan dan curah hujan di lintang menyebabkan terjadinya beberapa perbedaan tersebut. Penurunan salinitas permukaan dekat

\footnotetext{
${ }^{\odot}$ Copyright by Management of Aquatic Resources (MAQUARES)
} 
khatulistiwa disebabkan oleh curah hujan yang lebih besar atau tinggi. Menurut Febridayanti (2012) menyatakan bahwa nilai salinitas akan naik seiring dengan nilai kedalaman yang bertambah.

Suhu perairan pada stasiun 1 sampai 3 secara berurutan yaitu $31{ }^{\circ} \mathrm{C}, 30{ }^{\circ} \mathrm{C}$, dan $29,5{ }^{\circ} \mathrm{C}$. Keterkaitan suhu terhadap jarak dan kedalaman berbanding terbalik dengan salinitas, bertambahnya nilai kedalaman akan mempengaruhi naiknya nilai salinitas dan turunnya nilai suhu perairan (Febridayanti, 2012). Hal ini menunjukan bahwa kenaikan nilai jarak dan kedalaman mempengaruhi nilai suhu yang semakin menurun.

Kecerahan di Pantai Pancuran memiliki nilai $100 \%$ yang artinya cahaya matahari masih bisa menembus sampai ke dasar dari ketiga stasiun penelitian. Kecerahan perairan sangat berhubungan dengan kesuburan perairan yaitu berlangsungnya proses fotosintesis oleh lamun, sehingga menunjang peranannya sebagai produsen primer di perairan (Saputra, 2011 dalam Cahyani et al.,2014).

Derajat keasaman $(\mathrm{pH})$ di stasiun 1 memiliki nilai 8, sementara untuk stasiun 2 dan stasiun 3 memiliki nilai yang sama yaitu 7. Menurut Triyulianti et al., (2012) menyatakan bahwa konsentrasi $\mathrm{pH}$ cenderung mengalami penurunan untuk setiap penambahan kedalaman, hal ini diduga sebagai akibat dari hasil samping aktivitas fotosintesis dan respirasi organisme yang berasosiasi didalamnya.

Kecepatan arus di Pantai Pancuran pada stasiun 1 memiliki nilai 0,166 m/s, stasiun 2 memiliki nilai 0,125 m/s, dan stasiun 3 memiliki nilai $0,076 \mathrm{~m} / \mathrm{s}$. Menurut Tarhadi et al., (2014) yang menyatakan bahwa semakin bertambahnya kedalaman maka semakin berkurangnya kecepatan rata-rata arus karena adanya gesekan di tiap lapis kedalaman, serta adanya gesekan di dasar perairan turut mengurangi laju arus seiring bertambahnya kedalaman.

Pasang surut merupakan fenomena naik dan turunnya permukaan air laut. Stasiun 1 sampai 3 memiliki rata-rata surut masing-masingnya dengan nilai $-5,567 \mathrm{~cm},-6,086 \mathrm{~cm}$ dan $-7,413 \mathrm{~cm}$. Menurut Yudhantoko et al., (2016) menyatakan bahwa pasang surut dapat mempengaruhi kedalaman dan fungsi lamun sebagai sedimen trap sehingga saat pasang perairan menjadi jernih karena massa sedimen terperangkap oleh lamun, sedangkan pada saat surut massa air akan menggerus perairan sehingga tercampur menjadi muatan padatan yang mengakibatkan kekeruhan.

Karakteristik sedimen di Pantai Pancuran, Karimunjawa terdiri dari dua fraksi sedimen yaitu batu dan pasir. Fraksi batu terbagi menjadi dua partikel yaitu kerikil dengan persentase $12,02 \%$ dan butiran sebanyak 5,49\%. Fraksi pasir terbagi menjadi enam partikel yaitu pasir sangat kasar 6,03 \%, pasir kasar 12,83\%, pasir sedang 17,80\%, pasir halus 34,96\%, dan pasir sangat halus sebanyak 10,87\%. Menurut penelitian yang dilakukan oleh Cahyani et al., (2014) menyatakan bahwa tipe sedimen di Pantai Pancuran, Karimunjawa sebagian besar terdiri dari sand (pasir) dan gravel (pecahan karang).

\section{Struktur Komunitas Lamun}

Berdasarkan hasil penelitian di Pantai Pancuran, Karimunjawa diperoleh 6 jenis lamun yang tersebar dari stasiun 1 sampai dengan stasiun 3 diantaranya yaitu Thalassia hemprichii, Cymodocea rotundata, Halophila ovalis, Syringodium isoetifolium, Enhalus acoroides, dan Halodule pinifolia. Menurut penelitian yang dilakukan Ristianti et al., (2014) terdapat 7 jenis lamun yang tersebar di Pantai Pancuran, Karimunjawa yaitu Cymodocea rotundata, Cymodocea serrulata, Enhalus acoroides, Thalassia hemprichii, Halodule uninervis, Halophila ovalis, dan Halodule pinifolia.

Pada stasiun 1 dengan kedalaman 0,5 meter, Cymodocea rotundata memiliki kerapatan jenis tertinggi dengan jumlah 156 individu $/ \mathrm{m}^{2}$, Pada stasiun 2 dengan kedalaman 1 meter, Enhalus acoroides memiliki kerapatan jenis tertinggi yaitu 46 individu $/ \mathrm{m}^{2}$ Pada stasiun 3 dengan kedalaman 1,5 meter, Enhalus acoroides memiliki kerapatan paling tinggi yaitu 55 individu $/ \mathrm{m}^{2}$. Kerapatan jenis lamun dari stasiun 1 sampai dengan stasiun 3 menunjukan nilai kerapatan yang semakin kecil.

Hasil indeks ekologi komunitas lamun di Pantai Pancuran Karimunjawa pada 3 stasiun yang diamati memiliki nilai indeks keanekaragaman dengan kisaran antara 1, 013-1,335 yang artinya indeks keanekaragamannya sedang namun dengan nilai yang semakin meningkat. Hal ini didasarkan pada klasifikasi indeks keanekaragaman Shannon-Wienner yang membaginya kedalam 3 kategori yaitu indeks keanekaragaman rendah $\left(\mathrm{H}^{\prime}<1\right)$, indeks keanekaragaman sedang $\left(1 \leq \mathrm{H}^{\prime} \leq 3\right)$, dan indeks keanekaragaman tinggi $\left(\mathrm{H}^{\prime}>3\right)$. Menurut Septian et al., (2016) bahwa keanekaragaman mempunyai nilai tertinggi jika semua individu berasal dari spesies yang berbeda-beda, sebaliknya nilai terkecil diperoleh jika individu berasal dari spesies yang sama.

\section{Hubungan Jarak dan Kedalaman dengan Struktur Komunitas Lamun}

Jarak dan kedalaman memiliki kaitan yang kuat terhadap kerapatan dan indeks keanekaragaman yang mewakili struktur komunitas lamun di Pantai Pancuran, Kepulauan Karimunjawa. Jarak dan kedalaman terhadap kerapatan memiliki nilai korelasi $(r=-0.71766)$ yang masuk kategori memiliki korelasi kuat dengan kisaran 0,60-0,79 (Sugiyono, 2007). Nilai minus diperoleh karena nilai kerapatannya selalu menurun setiap bertambahnya kedalaman. Koefisien determinasi $\left(R^{2}\right)$ jarak dan kedalaman dengan kerapatan lamun memiliki nilai 1, dimana jarak dan kedalaman ini mempengaruhi kerapatan lamun sebesar $100 \%$.

Sementara itu, pengaruh jarak dan kedalaman terhadap indeks keanekaragaman lamun memiliki nilai korelasi $(\mathrm{r}=$ 0.89428). Menurut Sugiyono (2007) nilai korelasi ini menunjukan adanya hubungan yang sangat kuat antara jarak dan

\footnotetext{
${ }^{\circ}$ Copyright by Management of Aquatic Resources (MAQUARES)
} 
kedalaman terhadap indeks keanekaragaman lamun dengan kisaran nilai korelasi 0,80-1,00. Koefisien determinasi $\left(\mathrm{R}^{2}\right)$ memiliki nilai 1 yang artinya jarak dan kedalaman mempengaruhi indeks keanekaragaman sebesar 100\%. Berbeda dengan kerapatan, hubungan jarak dan kedalaman terhadap indeks keanekaragaman memiliki nilai positif yang artinya meningkatnya nilai jarak dan kedalaman berbanding lurus dengan kenaikan nilai indeks keanekaragaman lamun, hal ini berkaitan kuat dengan karakteristik dan tingkat adaptasi jenis lamun serta indeks keseragaman sebagai indikator kemerataan dan kesesuaian lingkungan.

\section{KESIMPULAN}

Jenis lamun yang ditemukan yaitu Thalassia hemprichii, Cymodocea rotundata, Halophila ovalis, Syringodium isoetifolium, Enhalus acoroides, dan Halodule pinifolia. Parameter kualitas perairan di Pantai Pancuran secara umum baik, dengan rata-rata nilai setiap parameternya masuk kedalam kisaran optimum yang mendukung siklus pertumbuhan dan perkembangan lamun. Karakteristik pasir halus mendominasi dengan persentase 34,960\%. Jarak dan kedalaman memiliki hubungan yang kuat terhadap struktur komunitas lamun. Jarak dan kedalaman berbanding lurus dengan indeks keanekaragaman namun berbanding terbalik terhadap kerapatan.

\section{UCAPAN TERIMA KASIH}

Penulis mengucapkan terimakasih kepada Balai Taman Nasional Karimunjawa (BTNKJ) atas bimbingan dan arahannya dalam penelitian ini.

\section{DAFTAR PUSTAKA}

Arikunto, Suharsimi. 2002. Metodologi Penelitian. Penerbit PT. Rineka Cipta. Jakarta.

Brower, J.E., J.H. Zar and V. Ende. 1990. Field and Laboratory Methods for General Ecology. USA: Wm.C. Brown Publisher.

BTNKJ. 2004. Laporan Interpretasi Wisata Bahari Taman Nasional Karimunjawa. BTNKJ. Semarang. 2008. Statistik BTNKJ Tahun 2008. BTNKJ. Semarang.

Cahyani, N.F.D, A. Hartoko, dan Suryanti. 2014. Sebaran dan Jenis Lamun Pancuran Belakang Pulau Karimunjawa, Taman Nasional Karimunjawa, Jepara. 3 (1) : 61-70.

Dobo J. 2009. Tipologi komunitas lamun kaitannya dengan populasi bulu babi di Pulau Hatta, Kepulauan Banda, Maluku. [Thesis]. Bogor: Sekolah Pascasarjana, Institut Pertanian Bogor.

Fachrul, F.M. 2007. Metode Sampling Bioekologi. Jakarta: Penerbit Bumi Aksara.

Febridayanti. I. 2012. Analisis Sebaran Suhu Dan Salinitas Secara Vertikal Di Perairan Pantai Barat Sumatera. [Tesis], Fakultas Matematika dan Ilmu Pengetahuan Alam Universitas Bengkulu.

Hutomo, H. 1997. Padang Lamun Indonesia: Salah Satu Ekosistem Laut Dangkal yang belum banyak dikenal. Jurnal Puslitbang Oseanologi-LIPI. Jakarta.

Krebs, C. J. 1989. Ecology: The Experimental Analysis of Distribution and Abundance, Second Edition. New York: Harper \& Row Publisher.

Millero, F.S dan M.L Sohn. 1992. Chemical Oceanography. CRC Pres. London.

Risamasu, F.J.L dan H.B. Prayitno. 2011. Kajian Zat Hara Fosfat, Nitrit, Nitrat dan Silikat di Perairan Kepulauan Matasiri, Kalimantan Selatan. Ilmu Kelautan. 16(3): 135-142.

Sambara, Z.R. 2014 Laju Penjalaran Rhizoma Lamun Yang Ditransplantasi Secara Multispesies Di Pulau Barrang Lompo [Skripsi]. Universitas Hasanuddin. Makassar

Septian, E.A., D. Azizah dan T. Apriadi. 2016. Tingkat Kerapatan dan Penutupan Lamun di Perairan Desa Sebong Pereh Kabupaten Bintan. Fakultas Ilmu Kelautan dan Perikanan. Universitas Maritim Raja Ali Haji.

Sugiyono. 2007. Metode Penelitian. Bandung: CV. Alfabeta.

Tarhadi, E. Indrayanti, A. Anugroho. 2014. Studi Pola dan Karateristik Arus Laut Di Perairan Kaliwungu Kendal Jawa Tengah Pada Musim Peralihan I . Jurnal Oseanografi. 3 (1) : 16-25.

Triyulianti Iis, D. Wijaya, W. Era, T. Arief, N. Widagti, P. Dipo, dan M. Trenggono. 2012. Distribusi Vertikal Ph Dan Alkalinitas Perairan Selatan Jawa Dan Samudera Hindia. [Semnas] IX Hasil Penelitian Perikanan dan Kelautan.

Tuwo, A. 2011. Pengelolaan Ekowisata pesisir dan Laut. Brilian Internasional. Sidoarjo.

Yudhantoko. M, G. Handoyo dan M. Zainuri. 2016. Karakteristik dan Peramalan Pasang Surut di Pulau Kelapa Dua, Kabupaten Kepulauan Seribu. Jurnal Oseanografi. 5 (3) : 368 - 377.

Zhang, L., Lu Wang, K. Yin, Ying Lü, Y. Yang, and X. Huang. 2014. Spatial and Seasonal Variations of Nutrients in Sediment Profiles and Their Sediment-Water Fluxes in the Pearl River Estuary, Southern China. Journal of Earth Science. 25(1) : 197-206.

\footnotetext{
${ }^{\circ}$ Copyright by Management of Aquatic Resources (MAQUARES)
} 